\title{
Preparation of inactivated tissue culture rabies vaccine adjuvanted with natural immune stimulants
}

\author{
H. M. Madbouly ${ }^{1}$, A. M. Nour El-Dien' ${ }^{2}$ Boseila A. H. Abeer ${ }^{2}$ \\ ${ }^{1}$ Deptartment of Virology, Faculty of Veterinary Medicine, Beni-Suef University, Beni-Suef, Egypt \\ ${ }^{2}$ National Organization for Drug Control and Research, Cairo, Egypt
}

\begin{abstract}
The challenge virus standard (CVS-11) strain of fixed rabies virus was propagated in weaning mice brains and in suckling mice brains. It was also propagated on baby hamster kidney cell line (BHK-21) with use of diethylaminoethyl-dextran (DEAEDextran). These passages were titerated in 3-4 weeks old white Swiss mice using mouse inoculation test (MIT). The virus harvest was concentrated using zinc acetate method, inactivated by beta-propiolactone (BPL) and adjuvanted with combination of vitamin $E$ and selenium. The prepared adjuvanted inactivated tissue culture rabies vaccine was subjected to quality control tests as safety, sterility and potency using National Institute of Health (NIH) test against reference vaccine.
\end{abstract}

Rabies virus was recognized in Egypt before 2300 B.C. and was described by Aristotle in ancient Greece. It has been characterized as one of the oldest and most life threating of both man and animals. It is the most lethal of all infectious diseases and has the widest host range of any virus [Fenner and White, 1994].

Fortunately, a prophylactic nervous tissue vaccine was introduced by Louis Pasteur. Many other nervous tissue vaccine had been developed, such as Semple vaccine. However, after they were injected, some nervous tissue vaccines induce severe allergic encephalomyelitis with an incidence of 1:1001:10000 (Kantorovich and Romanova 1974 and Li, 1981). Although duck embryo vaccine and suckling mouse brain vaccines had been used, these vaccines did not appear to be entirely devoid of risk (Held and Adaros 1972 and Rubin et al., 1973).

Canine vaccination compaigns became a reality with the development of modified-virus vaccines by serial chicken embryo passage (Koprowski and Cox, 1948). The severe reactions that accompanied exposure to nervous-tissue-derived human vaccines were avoided with the development of cell culture vaccines after by adapting fixed rabies virus to human diploid cell cultures (HDCS) (Wiktor and Koprowski, 1965). However, the highest cost and small yields of the HDCS vaccine have been limiting its use [Lin et al., 1983]. Rabies virus CVS-11 can be used for antigen production [Kissling, H. 1958]. The virus had been passaged 112 times in primary hamster kidney and 13 times in baby hamster kidney cell cultures BHK-21clone 13
[MacPherson and Stoker, 1962]. Inactivated vaccine was prepared from the CVS strain, cultivated in tissue culture, inactivated with phenol and tested in dogs, cats and foxes [Ott and Hyke 1962 a,b]. Kissling and Reese (1963) produced similar inactivated vaccine but was used for formalin after concentration. Another modification on these vaccine was applied by using an adjuvant (oil in water), thus prolonging immunity persist for more than 24 months [Kucera et al., 1969].

In this study, we try to prepare a new naturally adjuvanted tissue culture rabies vaccine using CVS-11 strain that was propagated on BHK-21 cell culture, concentrated by zinc acetate, inactivated by BPL and adjuvanted with combination of vitamin $\mathrm{E}$ and selenium.

\section{Material and Methods}

Virus. CVS-11 fixed rabies virus strain derived from the original Pasteur strain. It was prepared and fixed in mice brains. The virus strain was obtained from Abahyrab Company for Rabies Vaccine Production, India. It was propagated in mice for 22 times and had a titre of $10^{5.46}$ MICLD $_{50} / 0.03 \mathrm{ml}$.

Cell suspension. Baby hamster kidney (BHK21) cell line derived from the ATCC and cultured by the cell culture departement in VACSERA. It was grown in Eagle s minimum essential medium (Flow laboratories) supplemented with $10 \%$ fetal bovine serum (Gibco), 2mML-glutamine (Gibco), $50 \mathrm{ug} / \mathrm{ml}$ neomycin sulphate (Gibco) at $37^{\circ} \mathrm{C}$ in $5 \% \mathrm{CO}_{2}$ incubator.

Goat-antimouse Flourescein Isothiocyanate. It was obtained from Virology Department, 
Faculty of Veterinary Medicine, Cairo University. It was used for Indirect Fluorescent Antibody Technique according to (Smith et al., 1978).

DEAE - (Diethylaminoethyl) Dextran - HCl. It was purchased from Sigma Chemical Co. by NRA-NODCAR and used for propagation of CVS-11 on BHK-21 according to (Kaplan et al., 1967).

Commercial adjuvanted T.C. rabies vaccine for human use. Purified Rabies Vaccine (adjuvanted with aluminium hydroxide) applied for human vaccination, was used in NIH test. It had a potency of $2.5 \mathrm{IU} / \mathrm{ml}$.

MYOGASTER - E injectable solution. It's composition was :

(Vitamin E acetate $100 \mathrm{mg} / \mathrm{ml}$ and sodium selenite pentahydrate $2 \mathrm{mg} / \mathrm{ml}$ ). It was used for the prevention and treatment of muscular dystrophy and as immunostimulant in cattle, sheep, goat and poultry. It was used as a source for vitamin $\mathrm{E}$ and selenium in this work. It was produced by VMD, Belgium. Reg. No. : 1474/99 M.O.H. 26/10/99.

Propagation of CVS-11 rabies virus strain in weanling mice. The rabies virus was propagated in weanling mice (14-16g) using $0.03 \mathrm{ml}$ of $10^{-1}$ of the original virus after reconstitution and was inoculated intracerebrally according to (Webster and Dawson, 1935). Then the brains were harvested and titrated in weanling mice.

Propagation of CVS-11 rabies virus in suckling mice. The virus was propagated in suckling swiss mice by inoculating intracerebrally a dose of $0.01 \mathrm{ml}$ of the $10^{-1}$ of the virus. Brains were harvested during 3-5 days post inoculation or when symptoms were pronounced according to (Fuenzalida and Palacios 1955).

Propagation of CVS-11 rabies virus in BHK21 cell line. CVS-11 fixed rabies virus strain was passaged on BHK-21 cell line according to (Wiktor et al., 1964) with and without the use of DEAE-Dextran.Breifly, CVS-11 fixed rabies virus strain was propagated on BHK-21 cell line firstly without using DEAE-dextran for one passage and its titer was determined by mouse inoculation test. Then, the CVS-11 fixed rabies virus strain was propagated on BHK-21 cell line after pre-treatment of the cells with DEAEdextran (Diethylaminoethyl-dextran) 50ug / ml. Infected T.C. flasks were then incubated at $34^{\circ} \mathrm{C}$ for 3-4 days post inoculation till monolayer was formed. At the end of the $4^{\text {th }}$ d.p.i., the cells showed characteristic C.P.E. which was subjected to IFAT to confirm specificity of the C.P.E. Infected T.C. flasks were put in $-80^{\circ} \mathrm{C}$ and subjected to three cycles of freezing and thawing then clarified by centrifugation at 2500 r.p.m. $/ 30 \mathrm{~min} . / 4^{\circ} \mathrm{C}$.

Virus Titration. Propagated virus was titerated in mice and expressed in terms of the $\mathrm{LD}_{50} /$ $0.03 \mathrm{ml}$ according to the method of (Koprowski, 1973).

Virus Concentration. The BHK-21 propagated virus was concentrated by zinc acetate method according to the method described by (Sokol, 1973).Briefly, 50 parts of infected tissue culture fluid were mixed with one part of $1.0 \mathrm{M}$ zinc acetate solution ( $\mathrm{pH} 5.0)$. The mixture was allowed to stand at $4^{\circ} \mathrm{C}$ for $60 \mathrm{~min}$. with occasional agitation, then centrifuged at $1000 \mathrm{~g}$ for $20 \mathrm{~min}$. and the supernatant was discarded. The precipitate was resuspended to $1 / 10$ of the original volume in a MEM supplemented with Earl's salts, $0.2 \%$ bovine serum albumin and antibiotics with adjusting the $\mathrm{pH}$ to 7.4-7.6.

Virus Inactivation. The concentrated virus was inactivated using $\beta$-propiolactone (BPL) at a concentration of 1:4000 according to (Koprowski, 1973).

Preparation of the adjuvanted vaccine. Myogaster - E was diluted depending upon the LD50 of sodium selenite in mice $(0.9 \mathrm{mg} / \mathrm{kg}$ body weight) according to Toxic Rep.Ser. (1994) and for vitamin E (100 mg / kg body weight) according to (Toutain et al., 1992) then was mixed with the inactivated rabies virus at a ratio of 1:1 to make a homogenous mixture, kept at $4^{\circ} \mathrm{C}$ and subjected to quality control tests.

Quality Control of the prepared vaccine.

Safety Test. Ten mice, each weighing $18-20 \mathrm{~g}$, were inoculated intracerebrally with $0.03 \mathrm{ml}$ of the inactivated vaccine. All mice should be under observation for 30 days and any one animal showing signs of rabies after 5 days p.i. was considered positive for rabies. Another group number of suckling mice $<=4$ days of age were inoculated with $0.01 \mathrm{ml}$ of the prepared inactivated vaccine and kept for observation for at least 15 days p.i.

The safety test was done for inactivated vaccine before addition of adjuvants to ensure adequate inactivation of the vaccine.

Sterility Test. $1 \mathrm{ml}$ of inactivated vaccine was inoculated into at least 4 tubes of thioglycolate broth that was incubated at $37^{\circ} \mathrm{C}$ for 7 days and 
4 tubes of Sabouraud's agar that was incubated at $22^{\circ} \mathrm{C}$ for 15 days.

Abnormal Toxicity Test. 5 swiss mice weighing 13-16g, were inoculated intraperitoneally with $0.5 \mathrm{ml}$ of the inactivated vaccine and kept under observation for 7 days.

The end of the period each mouce was weighed, no loss or excess in weight should be observed and also no death should be occurring.

Potency Test. Potency test was done for the prepared adjuvanted vaccine by the NIH test according to the method described by (Seligmann, 1973).

\section{Results and Discussion}

Rabies is one of the oldest and most devastating viral diseases afflicting humans and animals. It was recognized in Egypt before 2300 B.C. and was described by Aristotle in ancient Greese. It is the most lethal of all infectious diseases and has the widest host range of any virus (Fenner and White, 1994). In earlier times, rabies was thought to be primarily a disease of dogs since rabies in humans usually developed following the bite of a rabid dog (Greene et al., 1984).

Rabies virus was thought to have originated in Africa, a belief based upon the diversity of closely related viruses that occur in that region (Beran et al., 1981). Rabies is present in all continents except Australia and Antaractica.

The ideal method for controlling rabies virus in both man and animals is by using active immunization injecting either live attenuated or inactivated rabies vaccines. The live attenuated vaccines had its great disadvantages as residual pathogenicity (Wachendorfer, 1976) and the possibility of reversion to virulence (Clark, 1980). The WHO's experts recommended that " No vaccines containing living virus could be used in man" (WHO, 1973) and U.S. authorities recommended the use of inactivated vaccines in animals (CDC, 1978).

The inactivated rabies vaccines were firstly produced from the nervous tissues of rabbits (Pasteur , 1881), sheep and goat (Fermi , 1908 and Semple , 1919) and suckling mouse brain (Fuenzalida et al., 1964) or produced from chicken embryo origin (CEO) (Peck et al., 1955). Such vaccines were antigenically potent and inexpensive to produce, however, the nervous tissue (N.T.) and chicken embryo contains a great encephali-togenic components (mainly protein) which can cause neurologic complications that were avoided by the development of cell culture vaccines after
Wiktor and Koprowski adapted fixed rabies virus to human diploid cell cultures HDCS (Wiktor and Kopowski, 1965). But the high cost and small yields of the HDCS vaccine had been limitted its use Lin et al., (1983).

C.V.S. mouse adapted strain was propagated on BHK-21 till reaching a titer of $10^{4.1}$ MICLD50 / $0.03 \mathrm{ml}$ when titerated in weaned mice and this result was agreed with that of Kissling, R.E. (1958) who was able to obtain mouse titers of $10^{3.5}$ MICLD50 utilizing the C.V.S. strain in primary cultures of hamster kidney.

Table (1) showed that titers of C.V.S.on BHK-21 was increased from $10^{1.84}$ to $10^{4.1}$ MICLD50 / $0.03 \mathrm{ml}$ after treatement of BHK21 cell line with $50 \mathrm{ug} / \mathrm{ml}$ of DEAE-dextran. These results agreed with ( Kaplan et al., 1967) who found that adsorption and penetration of virus could be enhanced by the presence of polyions, diethylaminoethyl-dextran (DEAEdextran) $50 \mathrm{ug} / \mathrm{ml}$ during virus absorption and also agreed with Zavadova and Svrcek, (1994) who used DEAE-dextran in an assay prepared on the cell culture BHK-21 / C13 [rabies infection test - RTCIT] for primary isolation and titration of street strains of the rabies virus from brains of suspected animals, to increase the invasiveness of the virus in the samples tested.

BHK cell line had been used for years in the production of rabies vaccine for animals. Lalosevic et al., (2001) stated that according to the latest recommendations of the Expert Committee for the Biological Standardization of the WHO from 1998, residual cellular DNA in the vaccine is not a potential risk because the inactivation of the virus by beta-propiolactone (BPL) completely inactivates its possible biological activity and so it could be used for preparation of human vaccines safely. BPL was used as shown by Koprowski, (1973) in a concentration of $1 / 4000$ for complete inactivation of rabies virus strain prepared on HDCS.

In this study, we used BHK-21 cell line to prepare inactivated rabies vaccine using CVS strain (its origin is the Pasteur strain which was used in the preparation of most inactivated rabies vaccines commercially available for human use), the propagated virus was concentrated 10-fold using zinc acetate precipitation method, inactivated using 1/4000 of BPL, adjuvanted using mixture of vitamin $\mathrm{E}$ and selenium and compared with the newly aluminium hydroxide adjuvanted inactivated T.C. rabies vaccine that 


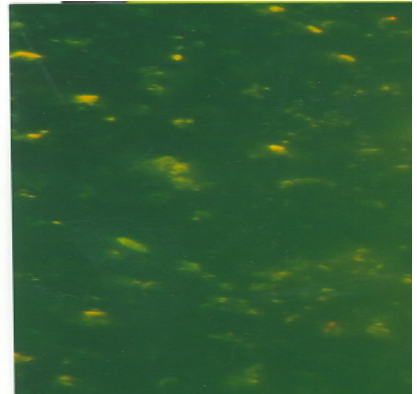

(A)

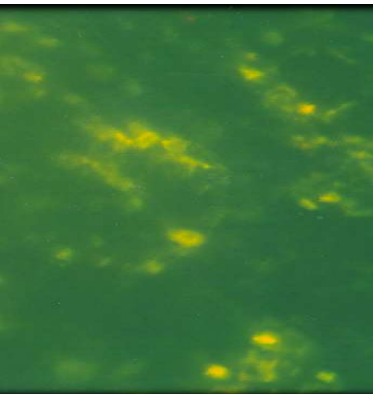

(A)

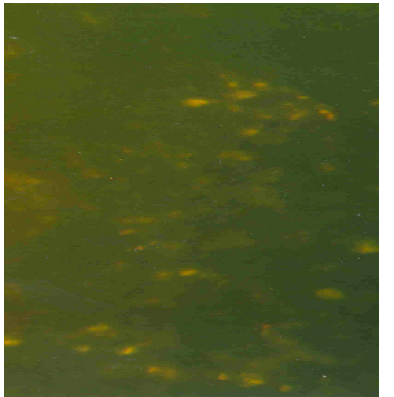

(B)

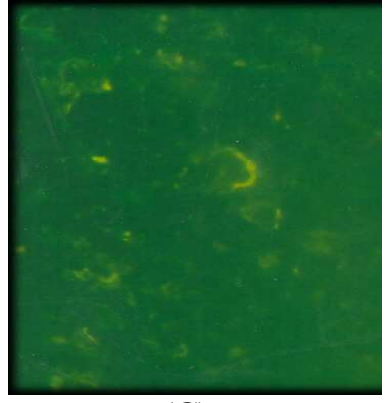

(C)

Demonstration of fixed rabies virus (CVS-11) strain in different host systems using Indirect Immunofluorescent Assay :
A) Suckling mouse brain.
B) Weaned mouse brain.
C) BHK21 cell line.

Table (1) : Infectivity titer of CVS-11 rabies virus strain.

\begin{tabular}{lcc}
\hline \multicolumn{1}{c}{ Passage No. } & Host & MICLD $_{\mathbf{5 0}}{ }^{*}\left(\log _{\mathbf{1 0}}\right)$ \\
\hline $\mathbf{2 3}^{\text {rd }}$ & Weaned mice & 5.5 \\
$\mathbf{3}^{\text {rd }}$ & Suckling mice & 6.84 \\
$\mathbf{1}^{\text {st }} \mathbf{P}$. without DEAE** & BHK-21 & 1.84 \\
$\mathbf{1}^{\text {st }}$ P. with DEAE** & BHK-21 & 4.1 \\
\hline
\end{tabular}

* MICLD50 = mice intracerebral lethal dose $50 / 0.03 \mathrm{ml}$

** DEAE = diethylaminoethyl-dextran.

Table (2) : Comparative efficacy of inactivated viral vaccines as tested by NIH potency test.

\begin{tabular}{|c|c|c|c|c|c|c|c|c|c|}
\hline \multirow[b]{2}{*}{ Dil. } & \multicolumn{3}{|c|}{ Plain vaccine } & \multicolumn{3}{|c|}{ Vit.E + selenium adjuvanted vaccine } & \multicolumn{3}{|c|}{ Commercial vaccine* } \\
\hline & $\begin{array}{c}\text { Mice } \\
\text { survived }\end{array}$ & $\begin{array}{l}\text { Total no. } \\
\text { of mice }\end{array}$ & $\begin{array}{c}\log _{10} \text { of } \\
\text { ED } D_{50} \text { end } \\
\text { point } \\
\text { dilution }\end{array}$ & $\begin{array}{c}\text { Mice } \\
\text { survived }\end{array}$ & $\begin{array}{l}\text { Total no. } \\
\text { of mice }\end{array}$ & $\begin{array}{c}\log _{10} \text { of } \\
\text { ED } D_{50} \text { end } \\
\text { point } \\
\text { dilution }\end{array}$ & $\begin{array}{c}\text { Mice } \\
\text { survived }\end{array}$ & $\begin{array}{l}\text { Total no. } \\
\text { of mice }\end{array}$ & $\begin{array}{c}\log _{10} \text { of } \\
\text { ED } D_{50} \text { end } \\
\text { point } \\
\text { dilution }\end{array}$ \\
\hline $10^{-0.7}$ & 9 & 10 & & 9 & 9 & & 9 & 9 & \\
\hline $10^{-1.4}$ & 4 & 10 & & 6 & 8 & & 8 & 9 & \\
\hline $10^{-2.1}$ & 2 & 7 & 1.484 & 2 & 9 & 1.827 & 4 & 7 & 2.142 \\
\hline $10^{-2.8}$ & 0 & 0 & & 1 & 7 & & 1 & 9 & \\
\hline
\end{tabular}

* This vaccine was adjuvanted using aluminium hydroxide and commercially used for human vaccination in Egypt.

Calculation of Potency.

R.P. (Relative Potency) $=$ reciprocal of $50 \%$ end point dilution of $\mathrm{TV} /$ reciprocal of $50 \%$ end point dilution of RV

X SDTV / SDRV

$\mathrm{TV}=$ tested vaccine.

$\mathrm{RV}=$ reference vaccine.

$\mathrm{SD}=$ single dose.

\section{For plain vaccine :}

$$
\begin{aligned}
\mathbf{R . P .} & =10^{1.484} / 10^{2.1} 42 \\
= & \mathbf{X} 2 / 1=10^{-0.658} \mathbf{X} 2 \\
& =\text { antilog of } 10^{-0.658} \mathbf{X} 2=0.22 \times 2=0.44
\end{aligned}
$$

For vit.E + selenium adjuvanted vaccine :

R.P. $=10^{1.827} / 10^{2.142} \times 2 / 1=10^{-0.315} \times 2$

$$
=\operatorname{antilog} \text { of } 10^{-0.315} \times 2=0.48 \times 2=0.97
$$

From the Wld. Hlth. Org. techn. Rep. Ser., 1973, No. 523.

When the volumetric test is used, the R.P. should be at least 0.3.

For alum-adsorped rabies vaccine :

$$
\begin{aligned}
\text { R.P. } & =10^{2.142} / 10^{1.827} \mathbf{X} 1 / 2=10^{0.315} \text { X } 0.5 \\
& =\text { antilog of } 10^{0.315} \text { X } 0.5=2.06 \times 0.5=1.03
\end{aligned}
$$


is available in Egypt and has been used commercially for humans.

The relative potency (R P) of NIH potency test of vit.E and selenium adjuvanted vaccine was 0.97 compared with the alum-adsorped vaccine and R.P.of the alum-adsorped vaccine was 1.03 compared with the prepared vit.E + selenium adjuvanted vaccine. The aim of this study is to investigate the powerful role of vitamin $E$ and selenium on the immune response and also as a trial to overcome the disadvantages of aluminium hydroxide that was showed by ( Redhead et al., 1992) to cause a transient rise in the level of brain tissue aluminium that peaks around the second and third day after intraperitoneal injection of alum adsorped vaccine into mice and this rise has not been seen in the saline control group and with vaccine not containing aluminium. Also Jefferson et al. (2004) noticed that alum-adsorped vaccine associated with local pain lasting up to 14 days in older children adminis-tered such vaccines. Verdier et al. (2005) observed histopathological lesions, similar to the Macrophagic Myofasciitis (MMF) described in humans, and was still present 3 months after aluminium phosphate and 12 months after aluminium hydroxide adjuvanted vaccine administration. In contrast to alum, Tengerdy and Lacetera, (1991) showed that vitamin $\mathrm{E}$, one of the antioxidant vitamins, is good immunopotentiators protecting the sensitive, rapidly proliferat-ing cells of the immune system from oxidation damage and increase cell-cell interaction by membrane alteration. Vitamin E adjuvants was tested against enterotoxaemia of sheep, ram epididymitis and E-coli infection of chicken. The vitamin E adjuvant was more effective than Fruend's Incomplete Adjuvant (FIA) or alumprecipitated aqueous antigen suspensions. In contrast, FIA causes a strong inflammatory reaction manifested by abscesses at the site of injection a matter that prevented its wide application in veterinary medicine and has been prohibited from being used in human medicine. Furthermore, the protective percentage of the prepared vaccine adjuvanted with vit.E and selenium was 100 $\%$ when used at $1 / 5$ dilution like as alum adjuvanted vaccine used in human with the same dilution. From the obtained results, the role of vitamine $\mathrm{E}$ and selenium as immunopotentiator is very clear when the vaccine compared with the plain virus and the role of DEAE-dextran in increasing the CVS rabies virus strain titers in BHK-21 is not neglected. Finally, we can recommended the use of this vaccine in vaccinating animals and/or humans for its safety, efficacy and potency and could replace other vaccines containing alum or encephalo-genetic proteins that induces severe allergic reactions.

\section{References}

Beran, G. W.; Currier, R. and Parker, R. L. (1981): Current concepts of rabies. Sci. Proc. Am. Coll. Vet. Intern. Med., pp : 31-48.

Center For Disease Control "CDC" (1978): Veterinary public Health notes. USDHEW, Zoonoses, Annual Summary, Rabies.

Clark, H. F. (1980): Rabies serogroup viruses in Neuroblastoma cells: Propagation, auto-interferance and apparantly back mutation of attenuated viruses to virulent state. Infec. Immunol., 27: 1012-1022.

Fenner, F. and White, D. O. (1994): Rabies and The Rhabdovirus. Med. Virology, San Diego, Academic Press.

Fermi, C. (1908) : Uber die immunisierung gegen Tollwat karankheit. Ztschr.F.Hyg.U.Infektionskr, 58: 233-276.

Fuenzalida, E. and Palacios, R. (1955): Bol. Inst. Bact. Chile, 8: 3-10.

Fuenzalida, E.; Palacios, R. and Borgono, J. M. (1964): Antirabies antibody response in man to vaccine made from infected suckling mouse brain. Bull.WHO, 30 : 431-436.

Greene, C. E; Hall, H. F.; Dreesen, D. W. and Chandler, F. W. (1984): Rabies. Clinical Microbiology and Infectious Diseases of the Dog and Cat, pp: 356-380.

Held, J. R. and Adaros, H. L. (1972): Neurological disease in man following administration of suckling mouse brain antirabies vaccine. Bull. W.H.O.46 : 321-327.

Jefferson, T.; Rudin, M. and Di Pietrantonj, C. (2004): Adverse events after immunisation with aluminiumcontaining DTP vaccines : systematic review of the evidence. Lancet Infect.Dis., 4 (2) : 84-90.

Kantorovich, R. A. and Romanova, L. N. (1974): Criteria of safety and test of innocence for new rabies vaccine.

International Symposium on Rabies. S.Karger, Basel, pp. 285-288.

Kaplan, M. M.; Wiktor, T. J.; Maes, R. F.; Campbell, J. B. and Koprowski, H. (1967): Using of the polyions in the adaptation of rabies virus in non nervous tissue culture. J. Virol., 1: 145.

Kissling, R. E. (1958): Growth of rabies virus in non nervous tissue culture. Proc. Soc. Exp. Biol. (N.Y.), 98: 223.

Kissling, R. E. and Reese, D. R. (1963): Antirabies vaccine of tissue culture origin. J.Immunol., 91: 362-368

Koprowski, H. (1973): The mouse inoculation test. Laboratory Techniques in Rabies, W.H.O., pp. 85-93.

Vaccine for man prepared from human diploid cells. Laboratory Techniques in Rabies, W.H.O., pp. 256-260

Koprowski, H. and Cox, H. R. (1948): Studies on chick embryo adapted rabies virus . J. Immunol., 60: 533.

Kucera, K. J.; Saudvig, D. C. and Johnson, A. F. (1969): 
A formalized and adjuvanted rabies vaccine of tissue culture origin. Propagation and evaluation of the vaccine. Biochem. Rev., 33 : 3-9.

Lalosevic, V.; Lazarevic-Ivanc, L. and Lalosevic, D. (2001): Clinical trial of YU BHK Rabivak vaccine against rabies in volunteers Med.Pregl., 54 Suppl. 1: 23-27.

Li, H. J. (1981): A survey on the complications of the nervous system following inoculation of the rabies vaccine. Chin. J. Epid., 2: 242.

Lin, F. ; Zeng, F. ; Lu, L. ; Lu, X. ; Zen, R. ; Yu, Y. and Chen, N. (1983) : The primary Hamster Kidney Cell Rabies Vaccine : Adaptation of Viral Strain, Production of Vaccine and Pre- and Postexposure Treatment. J Infect. Dis., 147 (3): 467-473.

McPherson, I. and Stocker, M. (1962) : Virol., 16: 147. Ott, G. I. and Hyke, B. (1962, a) : Preliminary trials of a new tissue culture rabies vaccine. Vet. Med., 57 : 158-159.

Ott, G. I. and Hyke, B. (1962, b) : Propagation of rabies virus, evaluation of a vaccine. Vet. Med., 57 : 613-615.

Pasteur, L.; Chamberland, S. and Roux, E. (1881): Sur une Maladie nouvalle provoque per la salive d'un enfant mor de la rage. C.R.Acad. Sci. , 92: 1259-1260.

Peck, F. B.; Powell, H. M. and Culberaston, C. G. (1955): A new Antirabies vaccine for human use : Clinical and laboratory results Using rabies vaccine made from embryonated duck eggs. J. Lab. Clin. Med., 45: 679-683.

Redhead, K.; Quinlan, G. J.; Das, R. G. and Gutteridge, J. M. (1992): Aluminium-adjuvanted vaccines transiently increase aluminium levels in murine brain tissue. Pharmacol Toxicol., 70 (4): 278-280.

Rubin, R. H.; Hattwick, M. A. W.; Jones, S.; Gregg, M. B. and Schwartz, V. D. (1973): Adverse reactions to duck embryo rabies vaccine: range and incidence. Ann. Intern. Med.,78 : 643-649.

Seligmann, J. R. E. B. (1973): The NIH test for potency. Laboratory Techniques in Rabies, W.H.O., pp. 279-286.

Semple, D. (1919): On the nature of rabies and antirabic treatment. Brit.Med.J., 2: 393-396.

Smith, A. L.; Tignor, G. H.; Emmons, R.W. and Woodie, J. D. (1978): Isolation of field rabies virus in CER and murine neuroblastoma cell cultures. Intervirol., 9: 359361.

Sokol, F. (1973) : Purification of rabies virus and isolation of its components. Laboratory Techniques in Rabies, W.H.O., pp. 165-178.

Tengerdy, R. P. and Lacetera, N. G. (1991): Vitamin E adjuvant formulations in mice. Vaccine, 9 (3): 204-206. Toutain, P. L.; Laurentie, M. P.; Hidiroglou, N. and Hidiroglou, M. (1992) : Vitamin E kinetics after intraperitoneal administration of DL-alpha-tocopherol and DL-alpha-tocopherol acetate in sheep. Ann. Res. Vet., 23 (2): 117-130.

Toxic Rep. Ser. (1994): NTP Toxicity Studies of Sodium Selenate and Sodium Selenite (CAS Nos. 13410-01-0 and 10102-18-8); 38: 1-E5

Verdier, F.; Burnett, R.; Michelet-Habchi, C.; Moretto, P.; Fievet-Groyne, F. and Sauzeat, E. (2005): Aluminium assay and evaluation of the local reaction at several time points after intramuscular administration of aluminium containing vaccines in the Cynomolgus monkey. Vaccine, 23 (11): 1359-67.

Wachendorfer, G. (1976): Gegenwertiger stand der vakzination van fuchsen gegan tollwut. Der Praktische Tierarzt, 12: 801-808.

Webster, L.T. and Dawson, J. R. (1935): Early diagnosis of rabies by mouse inoculation. Proc. Soc. Exp. Biol. Med., 32: $570-573$.

Wiktor, T. J. and Koprowski, H. (1965): Successful immunization of primates with rabies vaccine prepared in human diploid cell strain WI-38. Proc. Soc. Exp. Biol. Med. 118: 1069-1073.

Wiktor, T. J.; Fernandes, M. V. and Koprowski, H. (1964): Cultivation of rabies virus in human diploid cell strain WI-38 J. Immunol., 93, 353.

World Health Organization (1973): Expert committee on rabies, Sixth report, WHO technical report series No. 523: 19-50, Geneva.

Zavadova, J. and Svrcek, S. (1994): Improving the laboratory diagnosis of rabies and titeration of rabies viruses. Vet.Med. (Praha)., 39 (11) : 663-76. 